\title{
Molecular phylogeny and identification of the Egyptian wasps (Hymenoptera: Vespidae) based on COI mitochondrial gene sequences
}

\author{
Emtithal M. Abd-El-Samie ${ }^{1 *}$, Israa Elkafrawy ${ }^{2}$, Mai Osama² and Amr Ageez ${ }^{2,3}$
}

\begin{abstract}
The Hymenoptera is one of the vital and biggest insect orders comprising the bees, wasps, sawflies, and ants. Wasps are important to natural and biological pest control because they are predators or parasitoids of pest arthropods. This study investigated the genetic diversity among the three wasps, Vespa orientalis Linnaeus, Polistes bucharensis Erichson, and Polistes mongolicus du Buysson, collected from three different governorates in Egypt, using cytochrome oxidase subunit I (COI) DNA barcoding. PCR was performed to amplify COI fragment. The amplified COl regions (710 bp) were sequenced and analyzed. All novel nucleotide sequences of COI gene were deposited into the GenBank database. The genetic distances were estimated using Kimura two-parameter model. In spite of the wide geographical range, minor genetic diversity was observed between some populations of the three wasp species, revealing unrestricted gene flow between them. Phylogenetic relationship analysis was performed, using maximum likelihood (ML) method. The results of the phylogenetic analyses recovered $P$. bucharensis more closely related to $P$. dominula and $P$. gallicus. $P$. mongolicus collected from Menofia Governorate formed a distinct branch with $99 \%$ support. $V$. orientalis was sister to the yellowjacket Dolichovespula adulterine, with $84 \%$ support. It can be concluded that DNA barcode is a powerful tool for rapid and accurate identification of Egyptian wasp species.
\end{abstract}

Keywords: COl, Egypt, Hymenoptera, Vespidae, Phylogeny

\section{Background}

Wasps are predators or parasitoids of pest arthropods, so they are imperative to normal and biological control of pests (Hunt 2007). These insects have an essential part in pollination, a few of them in wax and honey production (Grissell 2010). The Vespidae are a large (about 5000 species), assorted cosmopolitan family of wasps, counting about all the known eusocial wasps (such as Polistes spp., Vespa orientalis, and Vespula germanica) and numerous single wasps (Grissell 2010). V. orientalis represents enormous issue for beekeepers (Haddad et al. 2005). The paper wasp genus Polistes Latreille, 1802, is an imperative model group for behavioral and developmental studies (Tibbetts 2007 and Jandt et al. 2014). It incorporates numerous eusocial species that show

\footnotetext{
* Correspondence: emtithal_a@yahoo.com; emtithal@sci.cu.edu.eg

${ }^{1}$ Faculty of Science, Cairo University, Cairo, Egypt

Full list of author information is available at the end of the article
}

different shapes of social organization. In addition, the comparatively little colony size of Polistes species and their uncovered nests encourage both field perceptions and tests (e.g., Cervo et al. 2008). Right now, over 220 species are recognized around the world (Arens 2011; Buck et al. 2012; Nugroho et al. 2012). Species identification is a crucial portion of recognizing and portraying biodiversity. Customarily, identification has been based on morphological diagnoses provided by taxonomic studies. Specialists such as taxonomists and prepared technicians can distinguish taxa accurately, since it requires extraordinary aptitudes acquired through extensive experience. Consequently, elective and accurate identification strategies that non-experts can use are required. Progresses in DNA sequencing innovations, advance in biotechnology, and the scientific classification crisis itself played a large role in the creation of DNA barcoding. Identification based on DNA barcode is very 
compelling at discriminating a constrained set of species, such as species occurring in a little range, agricultural pest species, and invasive species (Meier et al. 2008; Kress et al. 2009). Insects have been a major target of DNA barcoding due to their extraordinary diversity and their economic, agricultural, and epidemiological importance. However, DNA barcoding has several preferences. One advantage is its accessibility. The standard DNA barcode region, a part of COI, is exceptionally efficient for species identification. This locale has great discrimination power for most animal groups. The originally designed universal primer can be applied to all animal phyla (Hebert et al. 2003a,b, 2004). A short stretch of COI has enough information and can be straightforwardly sequenced with a sequencer. This is a protein-coding region so the alignment process is not difficult. Blunders can be identified by checking whether the obtained sequence is translatable. Sequence diversity in this gene could be utilized to make a "barcoding" framework that would enable the diagnosis of species of all animal life (Waugh 2007 for review; Hebert et al. 2010). These valuable highlights are the reason why the COI region was chosen as the standard DNA barcode. DNA barcoding can be a straightforward but effective strategy for non-experts, particularly those who routinely identify a large number of samples. Holometabolous insect orders, such as O:Hymenoptera, are greatly variable, and various endeavors have been made to relate their life stages using molecular markers (Miller et al. 2005; Ahrens et al. 2007; Sutou et al. 2007; Hayashi and Sota 2010; Kathirithamby et al. 2010; Murría et al. 2010; Pauls et al. 2010).

This study aimed to identify the three Egyptian wasp species by direct sequencing of the COI fragments and to estimate the differences of the wasp population based on their geographic aspects.

\section{Methods}

\section{Sample collection}

A total number of 120 specimens of wasps, representing three species (60 Vespa orientalis, 20 Polistes monogolicus, and 40 Polistes bucharensis) were collected from six different sites across three governorates in Egypt, with relatively different Egyptian agro-ecosystems: Menofia representing middle of the Delta (Lower Egypt), Giza representing the west bank of the Nile, and El-Fayoum representing Middle Egypt in September, 2017. Thirty-six specimens, out of 120 (three specimens of each species from each site), were randomly selected and used in this study (Table 1).

\section{DNA extraction}

Total genomic DNA was isolated from the head of each individual adult wasp, using QIAamp DNA mini kit (Qiagen, Valencia, CA, USA), according to the manufacturer's instructions. A final $100 \mu \mathrm{l}$ DNA extract was eluted and stored at $-20^{\circ} \mathrm{C}$ until molecular evaluation.

\section{PCR amplification}

The barcoding region of cytochrome c oxidase I gene was amplified by using primers: LCO1490 forward5'TT TCAACWAATCATAAAGATATTGG-3' and HCO2198 reverse 5 ' -TAA ACT TCW GGR TGW CCA AAR AAT CA- 3' (Cruaud et al. 2010). PCR was performed in triplicate using Master Mix (Qiagen). A $25 \mu \mathrm{l}$ reaction mixture contained $12.5 \mu \mathrm{l}$ of Master Mix, $2 \mu \mathrm{l}$ DNA template, 10 pmol of each primer. Using 3PrimePCR thermocycler (Techne, UK), reaction mixtures were initially incubated at $94{ }^{\circ} \mathrm{C}$ for $2 \mathrm{~min}$, followed by 35 cycles of amplification $\left(94{ }^{\circ} \mathrm{C}\right.$ for $30 \mathrm{~s}, 42{ }^{\circ} \mathrm{C}$ for $50 \mathrm{~s}$, and $72{ }^{\circ} \mathrm{C}$ for $35 \mathrm{~s}$ ), followed by final extension at $72{ }^{\circ} \mathrm{C}$ for $5 \mathrm{~min}$. PCR products were separated on $1.5 \%$ agarose gel, and bands visualized with GelRed staining (Biotuim) and UV transillumination.

Table 1 List of species, collection sites, and GenBank accession numbers of COI

\begin{tabular}{llll}
\hline Name & Accession number & Collection site & Species \\
\hline CU_1 & MG736622 & Giza (El-Mansoria) & Vespa orientalis \\
CU_2 & MG736623 & Giza (Abo-Rawash) & Vespa orientalis \\
CU_3 & MG736624 & Menofia (Ashmoon) & Vespa orientalis \\
CU_4 & MG736625 & Menofia (Quesna) & Vespa orientalis \\
CU_5 & MG736626 & El-Fayoum (El-Asfar) & Vespa orientalis \\
CU_6 & MG736627 & El-Fayoum (Abo-Dawood) & Vespa orientalis \\
CU_7 & MG736628 & Giza (El-Mansoria) & Polistes bucharensis \\
CU_8 & MG736629 & Giza (Abo-Rawash) & Polistes bucharensis \\
CU_9 & MG736630 & Menofia (Ashmoon) & Polistes mongolicus \\
CU_10 & MG736631 & Menofia (Quesna) & Polistes mongolicus \\
CU_11 & MG736632 & El-Fayoum (El-Asfar) & Polistes bucharensis \\
CU_12 & MG736633 & El-Fayoum (Abo-Dawood) & Polistes bucharensis
\end{tabular}

CU Cairo University 


\section{DNA sequencing}

Positive bands were purified using QIAquick Gel extraction kit (Qiagen ${ }^{\mathrm{Tx}}$, Germany), according to the kit instructions. Cycling sequence was performed with Big Dye Terminator Version 3.1 kit (Applied Biosystems, Foster City, CA), following manufacturer's instructions. The sequence-loaded plate run on automated machine (3500 analyzer) by colors laboratory (Cairo, Egypt), using the aforementioned primers.

\section{Phylogenetic analyses}

Sequence reads were edited and assembled, using the DNASTARsoftware (Lasergene, Madison, WI). Sequence similarity searches were confirmed, using BLASTN and BLASTX (https://blast.ncbi.nlm.nih.gov/Blast.cgi). The sequences were aligned, using Clustal $\mathrm{W}$ version 1.8 (Altschul et al. 1997). MEGA 7 software (Kumar et al. 2016) was used to perform the phylogenetic analysis. Phylogenetic trees of the cytochrome oxidase subunit I sequences were conducted with, using the maximum likelihood (ML) method (Felsenstein 1981; Kishino et al. 1990), and 1000 bootstrap replication was used to evaluate the branching confidence. Pairwise genetic distances were estimated using Kimura two-parameter model (Kimura 1980).

\section{Nucleotide sequence submission and GenBank accession numbers}

Accession numbers for each novel nucleotide sequence of COI gene of the Egyptian $V$. orientalis, $P$. monogolicus, and $P$. bucharensis are given in Table 1.

\section{Results and discussion}

This is the first time that the molecular data of wasps from the regions of El-Mansoria and Abo-Rawash (Giza), Ashmoon and Quesna (Menofia), and El-Asfar and Abo-Dawood (El-Fayoum) are presented, compared, and analyzed (Table 1). One specimen of each species from each site was sequenced. The results indicated that the amplified PCR products with COI primers were 710 nucleotides in length (Fig. 1). The710 bp target fragment incorporates the DNA barcode region of the animal taxa. Sequence diversity in this region was used as a tool for species discrimination (Hebert et al. 2003b). The nucleotide sequences of the $\mathrm{COI}$ for the three species of wasps under study were submitted to GenBank and subjected to a homology search using BLASTX. According to the sequence similarity, the local isolates could be identified as members of $V$. orientalis Linnaeus, $P$. bucharensis Erichson, and P. mongolicus du Buysson. Multiple sequence alignment was performed, using Clustal W (MEGA 7). A bootstrap phylogenetic tree based on COI sequences of the local isolated wasps and other species was constructed using neighbor joining (NJ) and maximum likelihood (ML) methods with Kimura twoparameter model. Both trees resulted in the same topological structure and confirmed the identification of all specimens based on COI gene. So, only ML tree is represented here. At the species level, ML tree topology reflected a strong relation between $V$. orientalis, collected from different localities in Egypt, which clustered together with $100 \%$ support with other $V$. orientalis isolates found in GenBank and with 84\% support with Dolichovespula adulterine (Fig. 2). The genus-level relationships of vespine wasps have been studied by many

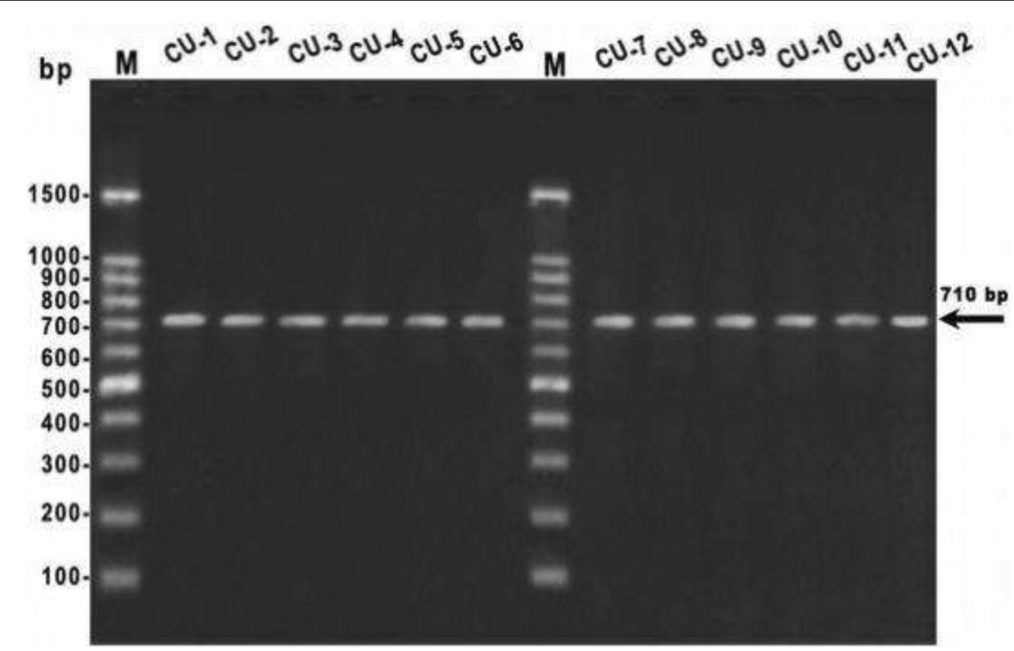

Fig. 1 Agarose gel showing polymerase chain reaction (PCR) results using DNA templates from different governorates with the primer sets LCO1490/HCO2198 for COI. M, marker (100 bp DNA Ladder RTU); Lanes CU_1 and CU_2 Vespa orientalis and CU_7 and CU_8 Polistes bucharensis collected from Giza; CU_3 and CU_4 Vespa orientalis and CU_9 and CU_10 Polistes mongolicus collected from Menofia. CU_5 and CU_6 Vespa orientalis and CU_11 and CU_12 Polistes bucharensis collected from Fayoum, respectively of the head of the adult individual 


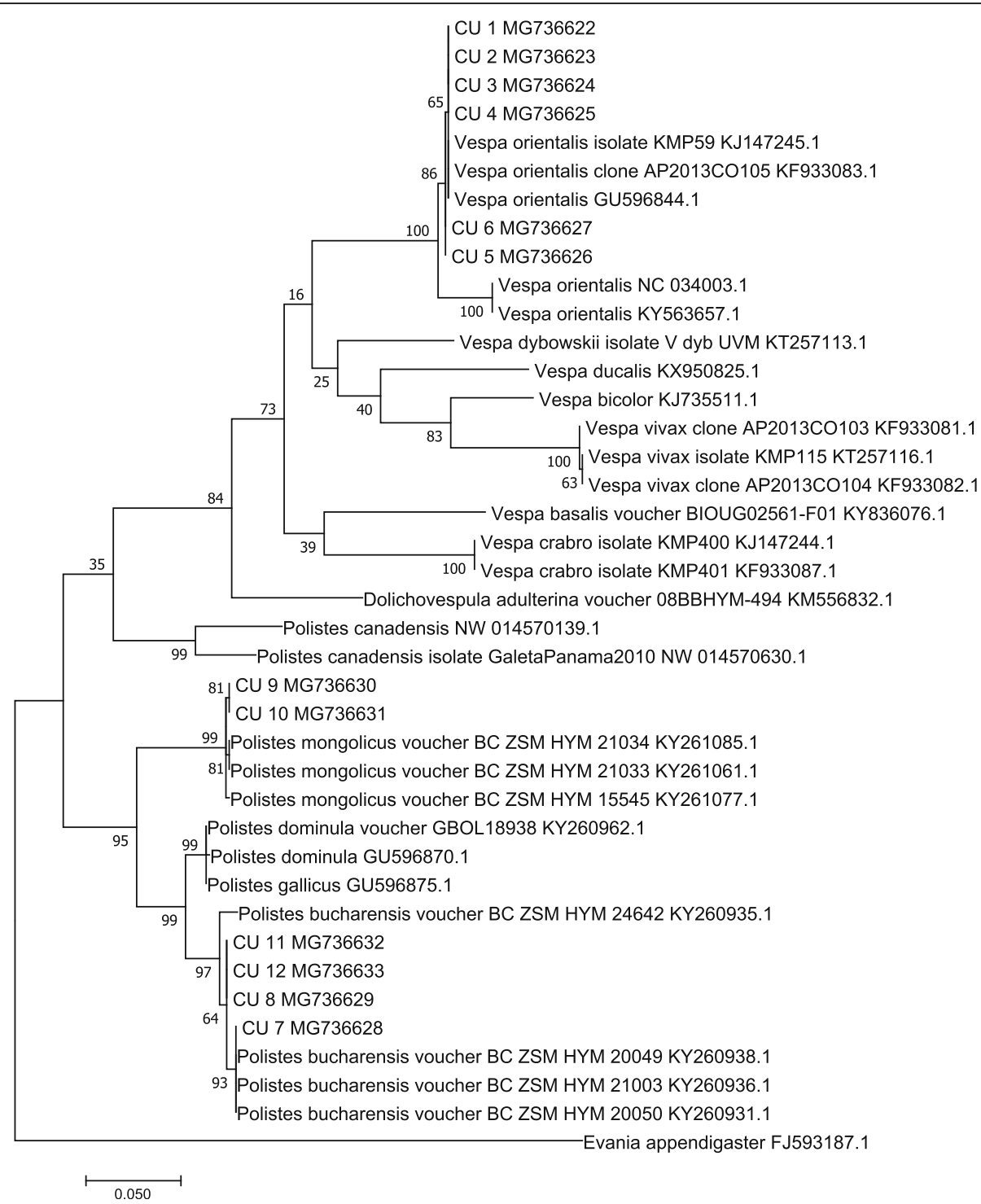

Fig. 2 Maximum likelihood tree of CO1 sequences from Vespa orientalis, Polistes monogolicus, and Polistes bucharensis collected from three different governorates in Egypt (accession no. CU_1 MG736622-CU_12MG736633). The nodes are shown with their bootstrap values; Evania appendigaster was used as the out-group

authors. They have recovered yellowjackets as a monophyletic group (Carpenter 1987; Pickett and Carpenter 2010; Saito and Kojima 2011; Perrard et al. 2016). Recently, Lopez-Osorio et al. (2017) found that the hornet genus Vespa is sister to the yellowjacket genus Dolichovespula. This result agreed with our results (Fig. 2). One of the vital factors related with population differentiation is the geographical isolation; the greater the geographical distance between populations, the less chance of gene flow; thus, there should be more differentiation between them (Zhang and Kang 2005). To test for a topographically based distribution of genetic diversity, we carried out the pairwise distance inside the $V$. orientalis group which showed that strains isolated from Giza and Menofia Governorates,
CU_1, CU_2, CU_3, and CU_4, were exactly the same. Moreover, they showed no difference with the Egyptian reference strain isolated in 2013 (Carpenter et al. 2013) and strain isolated from Cyprus (Pickett and Carpenter 2010). These results could be explained by the findings of Kumar et al. (2001) who reported that gene flow between populations was independent of geographic distance. Moreover, in the phylogenetic tree, the results indicated that isolated $V$. orientalis strains from Jordan (accession numbers: NC034003 and KY563657) were closely related to the Egyptian strains, collected from the three different governorates with $100 \%$ support (Fig. 2). This might be due to the wide distribution of $V$. orientalis in Egypt, Jordan, and Israel, where the social wasp fauna (Vespinae, 
Polistinae) in Jordan is similar to faunas of Israel and Egypt (Zalat 1992; Haddad et al. 2007) while strains isolated from El-Fayoum Governorate, CU_5 and CU_6, had minor sequence variation from the other collected species (Table 2, A). This may due to that El-Fayoum Governorate includes different climate and the type of cultivated crops differs from those of the Nile Valley. This suggested that other than geographical distances, neighborhood conditions had a high impact on the $V$. orientalis population structure and may strongly influence gene flow between sites, even on a very little scale. Based on our COI analysis, gene flow among the four populations of $V$. orientalis collected from Giza and Menofia had apparently occurred. Meanwhile, restricted gene flow might exist between them and the populations collected from EL-Fayoum. In addition, the tree topology reflects a strong relation between P. bucharensis, collected from Giza and El-Fayoum Governorates, which lie in close proximity and are included within a single cluster in the phylogenetic tree, regardless the collection sites with 97\% support with the isolated strain from Greece (accession number: KY260935). The pairwise distance calculation inside the $P$. bucharensis group showed that the collected P. bucharensis species were identical with a minor sequence variation to strain CU_7. This variation might be due to host plant differences and geographic locations. Strain CU_7 was identical to the reference strains, isolated from Cyprus (accession numbers: KY260936 and KY260938) (SchmidEgger et al. 2017) (Table 2, B). P. bucharensis showed a strong relation with $P$. dominula and $P$. gallicus (Fig. 2). In a similar study, $P$. bucharensis was settled inside the $P$. dominula cluster in both the phylogenetic analysis and the neighbor joining (Schmid-Egger et al. 2017). From the tree of this study, it is an evident that $P$. mongolicus, collected from Menofia Governorate (CU_9 and CU_10), formed a distinct branch with $81 \%$ support which was previously reported by Schmid-Egger et al. (2017) that in N Africa $P$. mongolicus is restricted to Egypt. In addition, the tree reflects a strong relation between CU_9 and CU_10 strains which clustered together with $99 \%$ support with the isolated strains from different localities in Cyprus (accession numbers: KY261085, KY261061, and KY261077) (Fig. 2). These results indicated that minor genetic diversity was observed between some populations of the three wasp species collected from different sites across the three governorates, revealing unlimited gene flow between them. Migration resulted in unrestricted gene flow between populations of the moth Scirpophaga incertulas (Kumar et al. 2001). Evania appendigaster, which was taken as an outgroup, creates a clear branch outside for reference. All nodes in the phylogenetic tree were well supported with strong bootstrap values. As far as we know, this is the first study regarding the molecular identification of the Egyptian wasps observed among some diverse areas across the country. In this study, the target species, $V$. orientalis and $P$. bucharensis and P. mongolicus were identified based on homology and phylogenetic investigations conducted for COI mitochondrial gene. Molecular analysis utilizing fundamental computer program was effective in their identification and distinguishing them from other

Table 2 Pairwise genetic distances of the analyzed COI gene inside the Vespa orientalis group (A) and inside the Polistes bucharensis group (B). The pairwise distance was calculated using the Kimura two-parameter model

\begin{tabular}{|c|c|c|c|c|c|c|c|c|c|}
\hline \multicolumn{10}{|l|}{ A } \\
\hline & & 1 & 2 & 3 & 4 & 5 & 6 & 7 & 8 \\
\hline 1 & CU_1_MG736622 & 0.000 & & & & & & & \\
\hline 2 & CU_2_MG736623 & 0.000 & 0.000 & & & & & & \\
\hline 3 & CU_3_MG736624 & 0.000 & 0.000 & 0.000 & & & & & \\
\hline 4 & CU_4_MG736625 & 0.000 & 0.000 & 0.000 & 0.000 & & & & \\
\hline 5 & CU_5_MG736626 & 0.002 & 0.002 & 0.002 & 0.002 & 0.000 & & & \\
\hline 6 & CU_6_MG736627 & 0.002 & 0.002 & 0.002 & 0.002 & 0.000 & 0.000 & & \\
\hline 7 & Vespa_orientalis_KF933083.1 & 0.000 & 0.000 & 0.000 & 0.000 & 0.002 & 0.002 & 0.000 & \\
\hline 8 & Vespa_orientalis_GU596844.1 & 0.000 & 0.000 & 0.000 & 0.000 & 0.002 & 0.002 & 0.000 & 0.000 \\
\hline \multicolumn{10}{|c|}{ B } \\
\hline & & 1 & 2 & 3 & 4 & 5 & 6 & & \\
\hline 1 & CU_7_MG736628 & 0.000 & & & & & & & \\
\hline 2 & CU_8_MG736629 & 0.005 & 0.000 & & & & & & \\
\hline 3 & CU_11_MG736632 & 0.005 & 0.000 & 0.000 & & & & & \\
\hline 4 & CU_12_MG736633 & 0.005 & 0.000 & 0.000 & 0.000 & & & & \\
\hline 5 & Polistes_bucharensis_KY260938.1 & 0.000 & 0.005 & 0.005 & 0.005 & 0.000 & & & \\
\hline 6 & Polistes_bucharensis_KY260936.1 & 0.000 & 0.005 & 0.005 & 0.005 & 0.000 & 0.000 & & \\
\hline
\end{tabular}


common species of wasps. Identification of many species based on COI and 16S rDNA has been reported previously (Boyer et al. 2011; Liu et al. 2011; Mc Donnell et al. 2011). Additionally, Li et al. (2010) used both barcode and nonbarcode sequences to reveal actual host utilization of figassociated Sycophila wasps (Hymenoptera: Eurytomidae). Moreover, 430,000 barcodes representing about 50,000 species of butterflies have been collected (Silva-Brandão et al. 2009; International Barcode of Life 2010b). On the other hand, nuclear genes, are required for discrimination between species when two groups of organisms have diverged very recently, may share the same DNA barcode(s), but may not belong to the same species (e.g., Hebert et al. 2003b; Kaila and Ståhls 2006; Langhoff et al. 2009; Burns et al. 2010; Žurovcová et al. 2010). Further work should be aimed at expanding sample sizes, taxa differences, and geographic populations to empower the creation of a DNA-based identification framework for wasps in Egypt.

\section{Conclusions}

The study supported the efficiency of COI DNA barcoding for accurate identification of $V$. orientalis, $P$. bucharensis, and $P$. mongolicus, collected from three different governorates in Egypt. Minor genetic variation was observed between some populations of the three wasp species under study, revealing unlimited gene flow between them. In the phylogenetic tree, the isolated $V$. orientalis strains from Jordan (accession numbers: NC034003 and KY563657) were closely related to the Egyptian strains collected from the three different governorates with $100 \%$ support. Also, the tree topology reflected a strong relation between $P$. bucharensis collected from Giza and El-Fayoum Governorates (with 97\% support) and other strain isolated from Greece (accession number: KY260935). In addition, P. mongolicus collected from two different sites of Menofia Governorates were more closely related to the isolated strains from different localities in Cyprus (accession numbers: KY261085, KY261061, and KY261077) with $99 \%$ support.

\section{Abbreviations \\ COI: Cytochrome oxidase subunit I; ML: Maximum likelihood method; NJ: Neighbor joining; P.: Polistes; V.: Vespa}

\section{Acknowledgements}

We thank the Scientific Research Sector, Faculty of Science, Cairo University for funding this study. We extend special thanks to the anonymous reviewer for his careful reading and concerned comments on the previous version of this article.

\section{Funding}

This work was financially supported by Scientific Research Sector, Faculty of Science, Cairo University.

\section{Availability of data and materials}

The datasets generated and analyzed during the current study are available in GenBank repository (https://www.ncbi.nlm.nih.gov/genbank/).

\section{Authors' contributions}

EMA designed the study, supervised the work, and wrote the manuscript with input from all authors. IE and MO carried out the experiments. AA analyzed the data. All authors read and approved the final manuscript.

Ethics approval and consent to participate

Not applicable

\section{Consent for publication}

Not applicable

\section{Competing interests}

The authors declare that they have no competing interests.

\section{Publisher's Note}

Springer Nature remains neutral with regard to jurisdictional claims in published maps and institutional affiliations.

\section{Author details}

${ }^{1}$ Faculty of Science, Cairo University, Cairo, Egypt. ${ }^{2}$ Faculty of Biotechnology, MSA University, 6 October City, Egypt. ${ }^{3}$ Agricultural Genetic Engineering Research Institute (AGERI), Agriculture Research Centre (ARC), Giza, Egypt.

Received: 17 January 2018 Accepted: 23 February 2018

Published online: 05 April 2018

\section{References}

Ahrens D, Monaghan MT, Vogler AP (2007) DNA-based taxonomy for associating adults and larvae in multi-species assemblages of chafers (Coleoptera: Scarabaeidae). Mol Phylogenet Evol 44:436-449

Altschul S, Madden T, Schaffer A, Zhang J, Zhang Z, Miller W, Lipman D (1997) Gapped BLAST and PSI-BLAST: a new generation of protein database search programs. Nucleic Acids Res 25:3389e3402

Arens W (2011) Die sozialen Faltenwespen der Peloponnes (Hymenoptera: Vespidae, Polistinae), mit Beschreibung einer neuen Polistes-Art und einem regionalen Polistes-Bestimmungsschlüssel. Linzer Biologische Beiträge 43(1): $443-481$

Boyer S, Blakemore RJ, Wratten SD (2011) An integrative taxonomic approach to the identification of three new New Zealand endemic earthworm species (Acanthodrilidae, Octochaetidae: Oligochaeta). Zootaxa 2994:21-32

Buck M, Cobb TP, Stahlhut JK, Hanner RH (2012) Unravelling cryptic species diversity in eastern Nearctic paper wasps, Polistes (Fuscopolistes), using male genitalia, morphometrics and DNA barcoding, with descriptions of two new species (Hymenoptera: Vespidae). Zootaxa 3502:1-48

Burns JM, Janzen DH, Hallwachs W (2010) Of many similar species in the Neotropical genus Porphyrogenes (Lepidoptera: Hesperiidae), a new one, repeatedly reared in Costa Rica, is relatively distinct. Proc Entomol Soc Wash 112:32-42

Carpenter J, Kojima Jl, Villemant C (2013) Phylogeny of hornets: a total evidence approach (Hymenoptera, Vespidae, Vespinae, Vespa). J Hymenopt Res 32:1

Carpenter JM (1987) Phylogenetic relationships and classification of the Vespinae (Hymenoptera: Vespidae). Syst Entomol 12:413-431

Cervo R, Dapporto L, Beani L, Strassmann JE, Turillazzi S (2008) On status badges and quality signals in the paper wasp Polistes dominulus: body size, facial colour patterns and hierarchical rank. Proc R Soc Lond B 275:1189-1196 https://doi.org/10.1098/rspb.2007.1779

Cruaud A, Jabbour-Zahab R, Genson G et al (2010) Laying the foundations for a new classification of Agaonidae (Hymenoptera: Chalcidoidea), a multilocus phylogenetic approach. Cladistics 26:359-387

Felsenstein J (1981) Evolutionary trees from DNA sequences: a maximum likelihood approach. J Mol Evol 17(6):368-376

Grissell E (2010) Bees, wasps, and ants: the indispensable role of Hymenoptera in gardens, 1st edn. Timber Press, Portland, p 11 20-21

Haddad NJ, Dvořák L, Adwan O, Mdanat H, Batayna A (2007) New data on Vespid wasp fauna of Jordan (Hymenoptera, Vespidae) Linzer biol. Beitr 39(1):137-142

Haddad NJ, Fuchs S, Haddaden J, Kopelke JP (2005) Record of Sphecophaga vesparum Curtis, a natural enemy of Vespa orientalis in northern Jordan. Zool Middle East 35(1):114-116

Hayashi M, Sota T (2010) Identification of elmid larvae (Coleoptera: Elmidae) from Sanin District of Honshu, Japan, based on mitochondrial DNA sequences. Entomol Sci 13:417-424 
Hebert PDN, Cywinska A, Ball SL, de Waard JR (2003b) Biological identifications through DNA barcodes. Proc R Soc B Biol Sci 270:313-321

Hebert PDN, deWaard JR, Landry JF (2010) DNA barcodes for 1/1000 of the animal kingdom. Biol Lett 6:359-362

Hebert PDN, Penton EH, Burns JM, Janzen DH, Hallwachs W (2004) Ten species in one: DNA barcoding reveals cryptic species in the neotropical skipper butterfly Astraptes fulgerator. Proc Natl Acad Sci U S A 101:14 812-14 817

Hebert PDN, Ratnasingham S, de Waard JR (2003a) Barcoding animal life: cytochrome c oxidase subunit 1 divergences among closely related species. Proc R Soc Lond Ser B 270:S96-S99

Hunt JH (2007) The evolution of social wasps. Oxford University Press, USA, p 261

International Barcode of Life 2010. Lepidoptera barcode of life. Available from URL: http://www.lepbarcoding.org/. [Cited 15 Oct 2010]

Jandt JM, Tibbetts EA, Toth AL (2014) Polistes paper wasps: a model genus for the study of social dominance hierarchies. Insect Soc 61(1):11-27 https://doi. org/10.1007/s00040-013-0328-0

Kaila L, Ståhls G (2006) DNA barcodes: evaluating the potential of COI to differentiate closely related species of Elachista (Lepidoptera: Gelechioidea: Elachistidae) from Australia. Zootaxa 1170:1-26

Kathirithamby J, Hayward A, McMahon DP et al (2010) Conspecifics of a heterotrophic heteronomous species of Strepsiptera (Insecta) are matched by molecular characterization. Syst Entomol 35:234-242

Kimura M (1980) A simple method for estimating evolutionary rate of base substitutions through comparative studies of nucleotide sequences. J Mol Evol 16:111-120

Kishino H, Miyata T, Hasegawa M (1990) Maximum likelihood inference of protein phylogeny and the origin of chloroplasts. J Mol Evol 31(2):151-160

Kress WJ, Erickson DL, Jones FA et al (2009) Plant DNA barcodes and a community phylogeny of a tropical forest dynamics plot in Panama. Proc Natl Acad Sci U S A 106:18621-18626

Kumar LS, Sawant AS, Gupta VS, Ranjekar PK (2001) Genetic variation in Indian populations of Scirpophaga incertulas as revealed by RAPD-PCR analysis. Biochem Genet 39(1-2):43-57

Kumar S, Stecher G, Tamura K (2016) MEGA7: molecular evolutionary genetics analysis version 7.0 for bigger datasets. Mol Biol Evol 33(7):1870-1874

Langhoff P, Authier A, Buckley TR, Dugdale JS, Rodrigo A, Newcomb RD (2009) DNA barcoding of the endemic New Zealand leafroller moth genera, Ctenopseustis and Planotortrix. Mol Ecol Resour 9:691-698

Li YW, Zhou X, Feng G et al (2010) COI and ITS2 sequences delimit species, reveal cryptic taxa and host specificity of fig-associated Sycophila (Hymenoptera, Eurytomidae). Mol Ecol Resour 10:31-40

Liu J, Li Q, Kong L, Yu H, Zheng X (2011) Identifying the true oysters (Bivalvia: Ostreidae) with mitochondrial phylogeny and distance-based DNA barcoding. Mol Ecol Resour 11:820-830

Lopez-Osorio F, Pickett KM, Carpenter JM, Ballif BA, Agnarsson I (2017) Phylogenomic analysis of yellowjackets and hornets (Hymenoptera: Vespidae, Vespinae). Mol Phylogenet Evol 107:10-15

Mc Donnell RJ, Rugman-Jones P, Backeljau T, Breugelmans K, Jordaens K, Stouthamer R, Paine T, Gormally M (2011) Molecular identification of the exotic slug Arion subfuscus sensu stricto (Gastropoda: Pulmonata) in California, with comments on the source location of introduced populations. Biol Invas 13:61-66

Meier R, Zhang G, Ali F (2008) The use of mean instead of smallest interspecific distances exaggerates the size of the "barcoding gap" and leads to misidentification. Syst Biol 57:809-813

Miller KB, Alarie Y, Wolfe GW, Whiting MF (2005) Association of insect life stages using DNA sequences: the larvae of Philodytes umbrinus (Motschulsky) (Coleoptera: Dytiscidae). Syst Entomol 30:499-509

Murría C, Zamora-Muñoz C, Bonada N, Ribera C, Prat N (2010) Genetic and morphological approaches to the problematic presence of three Hydropsyche species of the pellucidula group (Trichoptera:Hydropsychidae) in the western most Mediterranean Basin. Aquat Insects 32:85-98

Nugroho H, Kojima J, Carpenter JM (2012) Checklist of vespid species occurring in Indonesian archipelago. Treubia 38:71-186

Pauls SU, Blahnik RJ, Zhou X, Wardwell CT, Holzenthal RW (2010) DNA barcode data confirm new species and reveal cryptic diversity in Chilean Smicridea (Smicridea) (Trichoptera: Hydropsychidae). J N Am Benthol Soc 29:1058-1074

Perrard A, Lopez-Osorio F, Carpenter JM (2016) Phylogeny, landmark analysis and the use of wing venation to study the evolution of social wasps (Hymenoptera: Vespidae: Vespinae). Cladistics 32:406-425
Pickett KM, Carpenter MJ (2010) Simultaneous analysis and the origin of eusociality in the Vespidae (Insecta: Hymenoptera). Arthropod Syst Phylogeny 68:3-33

Saito F, Kojima J (2011) Phylogenetic analysis and biogeography of the nocturnal hornets, Provespa (Insecta: Hymenoptera: Vespidae: Vespinae). Species Divers 16:65-74

Schmid-Egger C, van Achterberg K, Neumeyer R, Morinière J, Schmidt S (2017) Revision of the West Palaearctic Polistes Latreille, with the descriptions of two species-an integrative approach using morphology and DNA barcodes (Hymenoptera, Vespidae). Zookeys 713:53-112

Silva-Brandão KL, Lyra ML, Freitas AVL (2009) Barcoding Lepidoptera: current situation and perspectives on the usefulness of a contentious technique. Neotropical Entomology 38:441-451

Sutou M, Kato T, Ito T (2007) Description of the final larval stage and the pupa of Ctenosciara japonica (Diptera: Sciaridae) and their DNA barcodes. Studia Dipterologica 14:17-22

Tibbetts EA (2007) Dispersal decisions and predispersal behavior in Polistes paper wasp workers. Behav Ecol Sociobiol 61:1877-1883 https://doi.org/10.1007/ s00265-007-0427-x

Waugh J (2007) DNA barcoding in animal species: progress, potential and pitfalls. BioEssays 29:188-197

Zalat SM (1992) The Vespidae (social wasps) of Egypt. J Egypt Ger Soc Zool 9(D): 247-258

Zhang M, Kang L (2005) Genetic divergence among geographical populations of the migratory locust in China. Sci China Ser C Life Sci 48(6):551-564

Žurovcová MA, Havelka JAN, Starý PETR, Vcchtová PA, Chundelová DA (2010) "DNA barcoding" is of limited value for identifying adelgids (Hemiptera: Adelgidae) but supports traditional morphological taxonomy. Eur J Entomol 107:147-156

\section{Submit your manuscript to a SpringerOpen ${ }^{\mathcal{O}}$ journal and benefit from:}

- Convenient online submission

- Rigorous peer review

- Open access: articles freely available online

- High visibility within the field

- Retaining the copyright to your article

Submit your next manuscript at springeropen.com 